\title{
Recombination Study of Dye Sensitized Solar Cells with Natural Extracts
}

\author{
Gideã T. Tractz, ${ }^{a}$ Aline Viomar, ${ }^{a}$ Bianca V. Dias, ${ }^{a}$ Camila A. de Lima, ${ }^{\oplus a}$ \\ Everson P. Banczek, ${ }^{a}$ Maico T. da Cunha, ${ }^{a}$ Sandra R. M. Antunes ${ }^{b}$ and \\ Paulo R. P. Rodrigues ${ }^{\circledR} *, a$ \\ ${ }^{a}$ Departamento de Química, Universidade Estadual do Centro Oeste, \\ Campus Centro Educacional de Desenvolvimento Tecnológico de Guarapuava (Cedeteg), \\ 85040-080 Guarapuava-PR, Brazil \\ ${ }^{b}$ Departamento de Química, Universidade Estadual de Ponta Grossa, \\ Campus Uvaranas, 84030-900 Ponta Grossa-PR, Brazil
}

\begin{abstract}
Natural dyes can be used in dye sensitized solar cells (DSSCs) to generate low-cost devices, although with low light harvesting because of energy losses from the recombination process. This study investigates recombination reactions in DSSCs with natural dyes extracted from eggplants, plums, and hibiscus flowers. Titanium dioxide films were coated on a fluorine-doped tin oxide glass conductor substrate by the doctor blading method and impregnated in a dye solution for $24 \mathrm{~h}$. Electrodeposited platinum was used as the cathode, and $\mathrm{I}_{3}^{-} / \mathrm{I}^{-}$as the redox couple. The techniques employed were: intensity modulated photovoltage spectroscopy, intensity modulated photocurrent spectroscopy, electrochemical impedance spectroscopy, charge extraction, and cyclic voltammetry. The results show that cells containing plum dye exhibited the best photovoltaic parameters, with high values of gap, charge extraction, and potential, being less resistive to charge transfer with an electron lifetime of $0.51 \mathrm{~s}$, collection time of $8.54 \mathrm{~ms}$, and charge efficiency collection of 0.99 .
\end{abstract}

Keywords: Gratzel cell, IMVS, IMPS photovoltaic devices

\section{Introduction}

The increasing energy demand to support economic growth and reduce the greenhouse effect caused by the oil product combustion, has led to the search for development of clean energy alternatives to fossil fuel combustion. ${ }^{1}$ Solar energy is an important resource because of its inexhaustibility and pollution-free character. ${ }^{1,2}$

Dye-sensitized solar cells (DSSCs) are devices that can convert sunlight to electricity by a photovoltaic effect, theoretically exceeding the Shockley-Queisser limit. ${ }^{2}$ Light harvesting is provided by the use of a semiconductor material with an ideal sensitizer, which can absorb the light and eject electrons to an excited state (lowest unoccupied molecular orbital (LUMO) level; Figure 1). ${ }^{3,4}$ The use of an electrolyte is necessary to intermediate the charges and allow an electron flow. ${ }^{5-7}$

The most promising method for light conversion in DSSCs is via nanocrystalline $\mathrm{TiO}_{2}$, sensitized with ruthenium complexes, such as cis-[Ru (2,2'-bipyridil-

*e-mail: prprodrigues@gmail.com 4,4'-dicarboxylic acid $\left.)_{2}(\mathrm{NCS})_{2}\right](\mathrm{N} 3)$ and $\left(\mathrm{Bu}_{4} \mathrm{~N}\right)_{2}[\mathrm{Ru}$ (2,2'-bypiridil-4,4'-dicarboxylic acid $)_{2}(\mathrm{NCS})_{2}$ ] (N719). However, these molecules have a high cost that gives impetus to the search for lower-cost materials such as natural dyes, containing flavonoids, as anthocyanins. ${ }^{7}$

Anthocyanins, present in a wide variety of flowers and fruits, have auxochrome groups such as $\mathrm{COOH}$ and $\mathrm{OH}$ that absorb light in a visible energy range from sunlight, in a less efficient way when compared with ruthenium-based dyes, but the cost can make their use viable. ${ }^{5}$ Energy conversion is promoted by the charge carriers, and the operational principle of DSSCs has important characteristics.

The generation and separation of charge carriers produce voltage and current in these devices, under solar illumination. ${ }^{6}$ Electron transport in nanocrystalline oxide can be limited by the reaction of the $\mathrm{I}_{3}{ }^{-}$before reaching the substrate or returning to the LUMO state, as depicted in Figure 1 (reactions 6-8). ${ }^{8}$ These reactions are known as recombination reactions, and they decrease the device solar energy efficiency. ${ }^{9}$

The key of the efficiency cell is the competition between reactions 3 and 7 (Figure 1). In reaction 3, the electrons 


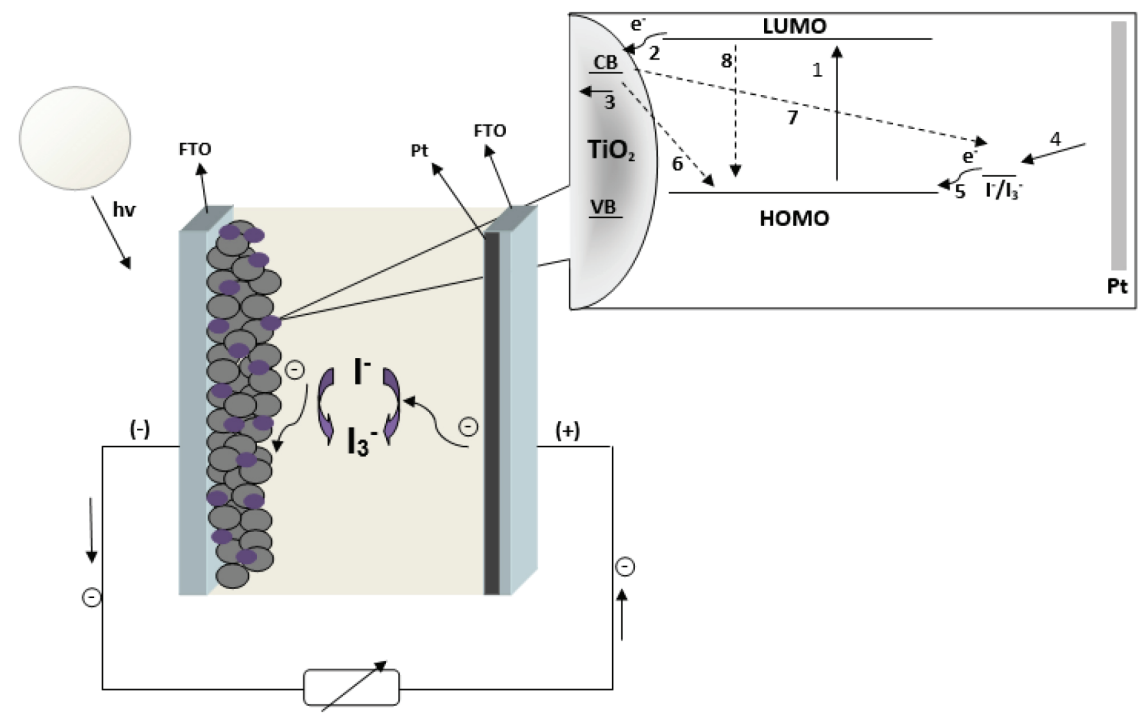

Figure 1. DSSC assembly with the interfacial reactions being: 1, photoexcitation; 2 , injection; 3 , transport; 4, diffusion; 5, regeneration; and 6-8, recombination charges.

move through the external circuit to meet the counter electrode, and, in reaction 7, the electrons in the $\mathrm{TiO}_{2}$ surface recombine with the oxidized dye according to the following reaction 9 (equation 1): ${ }^{5,8}$

$\mathrm{I}_{3}^{-}+2 \mathrm{e}^{-}\left(\mathrm{TiO}_{2}\right) \rightarrow 3 \mathrm{I}^{-}$

For devices made of the most efficient dyes, process 3 is much more rapid than process 7 , and recombination to natural dyes was not reported in the literature. These values are determined by photovoltage and photocurrent measurements using modulated and pulsed illumination. ${ }^{8}$

The aim of this paper is to study the recombination process in lower-cost dye sensitized solar cells produced with $\mathrm{TiO}_{2}$ and dyes extracted from different natural products, using electrochemical and optical measurements.

\section{Experimental}

For the extraction, $6.25 \mathrm{~g}$ of natural products, such as hibiscus flowers (Hibiscus sabdariffa), eggplant peel (Solanum melongena), and plum peel (Prunus domestica) were extracted with $65 \mathrm{~mL}$ of acidified ethanol solution (70\%) at $5{ }^{\circ} \mathrm{C}$ for $12 \mathrm{~h}$ and used as dye. ${ }^{10-13}$ Anthocyanidin is formed when the glucose group of an anthocyanin is removed upon acidification, and the less steric hindrances result in strong bonding to the $\mathrm{TiO}_{2}$ surface, generating cells with better parameters, as described by Kumara et al..$^{14}$ and Manhita et al. ${ }^{15}$

The photoanode was prepared with $3 \mathrm{~g}$ commercial $\mathrm{TiO}_{2}$ anatase ( $<25 \mathrm{~nm}$; Sigma-Aldrich), $0.1 \mathrm{~mL}$ of acetylacetone, $1 \mathrm{~mL}$ of polyethylene glycol $200,4 \mathrm{~mL}$ of deionized water, and $0.1 \mathrm{~mL}$ of Triton $\mathrm{X} .{ }^{10}$ The fluorine-doped tin oxide (FTO; ca. $7 \Omega \mathrm{sq}^{-1}$ ) glass was cleaned in a solution (70:30 water/ethanol) using an ultrasonic bath for $15 \mathrm{~min}$ and then dried. The $\mathrm{TiO}_{2}$ emulsion was coated on the FTO by employing the doctor blading technique, followed by calcination at $450{ }^{\circ} \mathrm{C}$ for $30 \mathrm{~min}$. The dyes were attached to the $\mathrm{TiO}_{2}$ surface by immersing the coated electrode in a dye solution for $24 \mathrm{~h}^{13}$

The platinum counter electrode was prepared by cyclic voltammetry using three electrodes: the FTO (working electrode), $\mathrm{Ag}_{(\mathrm{s})} / \mathrm{AgCl}_{(\mathrm{s})}$ (reference electrode) and platinum (counter electrode), at a scan rate of $10 \mathrm{mV} \mathrm{s}^{-1}$ with a supporting electrolyte prepared by $1 \times 10^{-4} \mathrm{~mol} \mathrm{~L}^{-1}$ $\mathrm{K}_{2} \mathrm{PtCl}_{6}$ dissolved in $0.1 \mathrm{~mol} \mathrm{~L}^{-1} \mathrm{HCl}^{16}$ The solar cell was assembled in a sandwich format (Figures $2 \mathrm{a}-2 \mathrm{c}$ ) with an electrolyte prepared with $0.5 \mathrm{~mol} \mathrm{~L}^{-1}$ tert-butylpyridine, $0.6 \mathrm{~mol} \mathrm{~L}^{-1}$ tetrabutylammonium iodide, lithium iodide, and $0.1 \mathrm{~mol} \mathrm{~L}^{-1}$ of resublimated iodine, solubilized in methoxypropionitrile. ${ }^{16}$ The active area used was $0.2 \mathrm{~cm}^{2}$.

The anthocyanidin present on the $\mathrm{TiO}_{2}$ film was confirmed by the increase in the color intensity of the film, to a brighter red coloration, when concentrated hydrochloric acid was added, as described by Narayan ${ }^{17}$ and Lim et al. ${ }^{18}$

Electrochemical measurements were performed in a Zhenium Zahner potentiostat with a solar simulator provided by a xenon lamp. The charge extraction (CE) method of DSSCs under controlled illumination intensity $\left(100 \mathrm{~mW} \mathrm{~cm}^{-2}\right)$ was extracted by short-circuiting the cell from an open-circuit potential with light on time and a discharge time of $10 \mathrm{~s}$ in a time extraction of $15 \mathrm{~s} \cdot{ }^{19,20}$ Electron transport time and electron lifetimes were measured by intensitymodulated photovoltage spectroscopy (IMVS) and intensitymodulated photocurrent spectroscopy (IMPS), in a frequency range between $100 \mathrm{mHz}$ and $1 \mathrm{kHz}$ under $100 \mathrm{~mW} \mathrm{~cm}^{-2}$. 

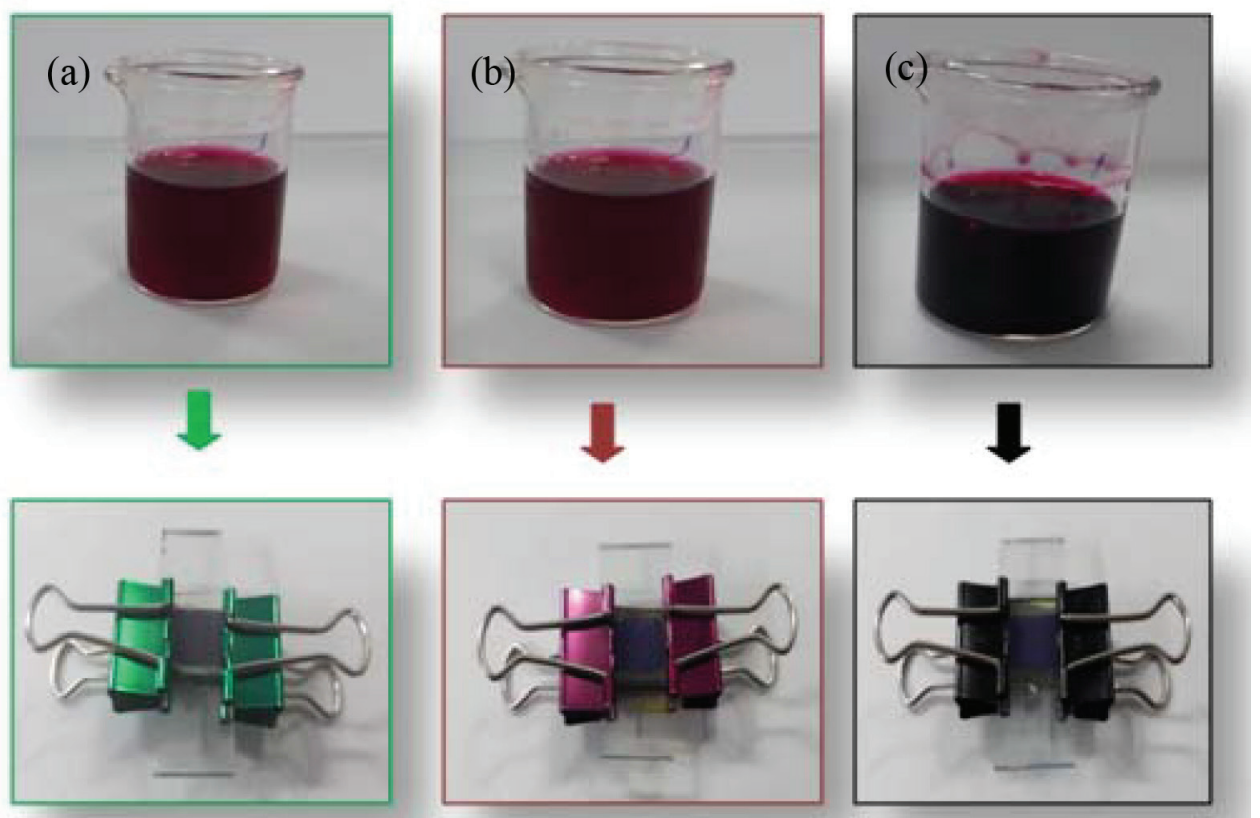

Figure 2. Natural dyes (a) plum; (b) eggplant; and (c) hibiscus, and the respective cell assemblies in sandwich format of anode and cathode.

The electrochemical impedance spectroscopy (EIS) analyses were recorded in the frequency range between $10 \mathrm{mHz}$ and $10 \mathrm{kHz}$ with an irradiance of $100 \mathrm{~mW} \mathrm{~cm}{ }^{-2}$ under standard illumination of air-mass 1.5 global (AM $1.5 \mathrm{G}$ ) and perturbation of $10 \mathrm{mV}$. Solar conversion efficiency measurement was tested in the same conditions.

The absorption spectra of dyes on $\mathrm{TiO}_{2}$ surface were obtained by an Ocean Optics spectrometer (USB-2000), coupled to a tungsten lamp and an optical fiber suitable for solid samples, in a range of 400 to $900 \mathrm{~nm}$.

Cyclic voltammetry measurements were carried out in three electrode systems, consisting of a glassy carbon working electrode, platinum counter electrode, and $\mathrm{Ag} / \mathrm{AgCl}$ reference electrode at a scan rate of $100 \mathrm{mV} \mathrm{s}^{-1}$. The

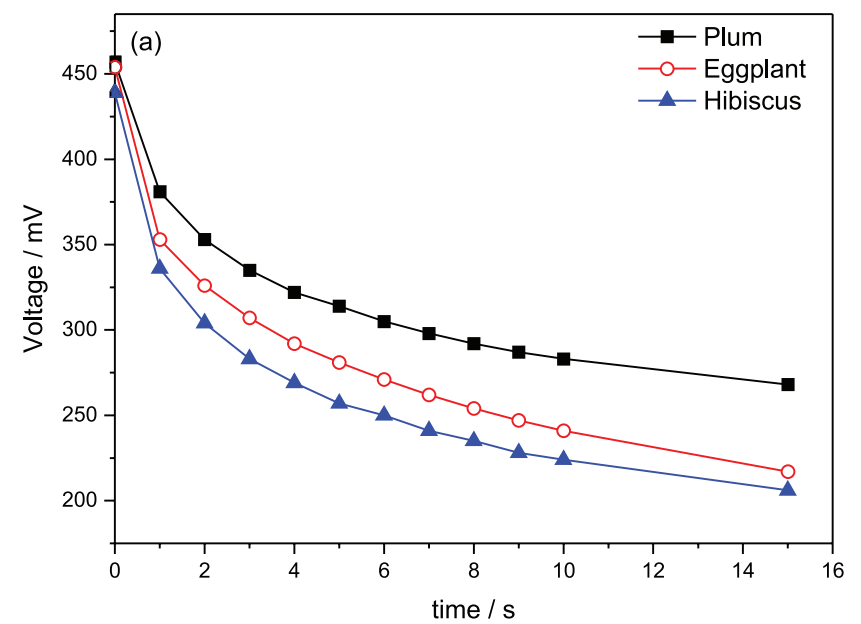

supporting electrolyte was $0.5 \mathrm{~mol} \mathrm{~L}^{-1} \mathrm{KCl}$ in distilled water. The voltammograms obtained, with UV-Vis spectra of the dyes on $\mathrm{TiO}_{2}$ surface, were used to calculate the energy level of the natural photosensitizers.

\section{Results and Discussion}

Figures $3 \mathrm{a}$ and $3 \mathrm{~b}$ illustrate photovoltage decay and the charge density of the photoanode, respectively, determined by the CE method as a function of time to all cells produced.

Figure 3a illustrates the time dependence of the photovoltage for the cells analyzed. When the lamp was switched on, the voltage attained values close to $450 \mathrm{mV}$. When the lamp was switched off, the voltage decayed over

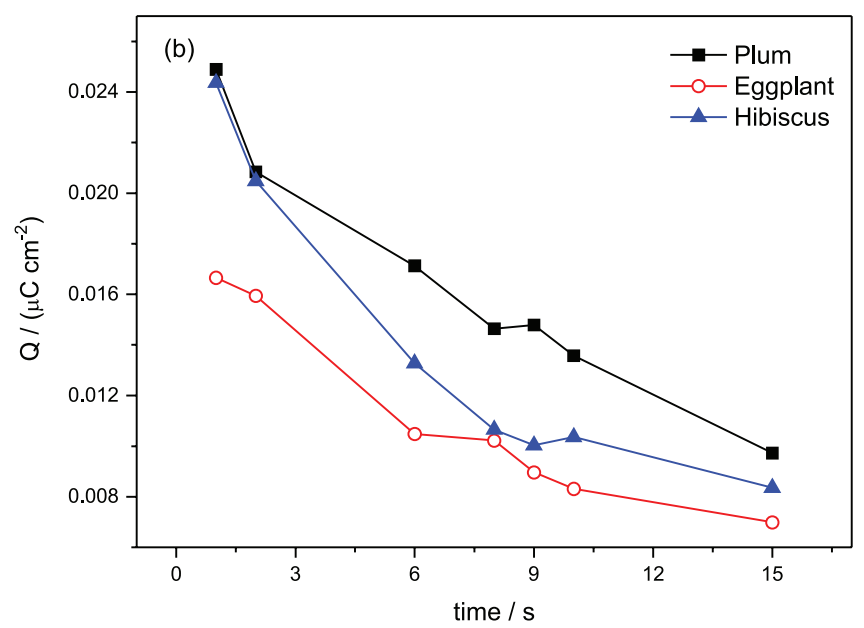

Figure 3. (a) Time-dependent photovoltage decay curves for DSSCs with natural dyes; and (b) CE transients obtained upon switching to the potentiostatic mode, after different delay times during the photovoltage decay in the dark for DSSCs with natural dyes. 
a period of seconds. Because the extract current is zero, a decrease in voltage can only be attributed to recombination electrons transferred to the electrolyte or oxidized dye molecules (reactions 6-8, Figure 1). ${ }^{8,19}$ Finally, the cell was short-circuited $\left(\mathrm{j}_{\mathrm{sc}}\right)$ and the charge was calculated and used to verify the electron concentration on $\mathrm{TiO}_{2}$ photoanode (Figure 3b). ${ }^{8,20-22}$

The results in Figure 3a indicate high values of voltage decay to cells sensitized with plum ( $380 \mathrm{mV}$ in $1 \mathrm{~s}$ decay) when compared with other systems. This measurement, when accompanied with $\mathrm{CE}$ in Figure $3 \mathrm{~b}$ that showed more electron density in $\mathrm{TiO}_{2}$ photoanode to the same cell $\left(0.025 \mu \mathrm{C} \mathrm{cm}^{-2}\right)$, indicated that recombination reactions are more pronounced in the cell produced with the dye extracted from eggplant. ${ }^{8,23}$ The lower concentration of active substances, dye adsorption of anchoring groups on $\mathrm{TiO}_{2}$ surface, and position of auxochromes and chromophore groups may be responsible for the result, but they have not been evaluated independently. ${ }^{24}$

The most favorable result, comparing the natural dyes tested, was the cell using the plum dye, with an initial photovoltage of $458 \mathrm{mV}$, and the lowest was the eggplant cell with $0.017 \mu \mathrm{C} \mathrm{cm}^{-2}$ of $\mathrm{CE}$ in $1 \mathrm{~s}$ with $438 \mathrm{mV}$ of initial photovoltage. ${ }^{9,25}$

The IMVS curve depicted in Figure 4a and IMPS in Figure $4 \mathrm{~b}$ were obtained and used to calculate the collection time $\left(\tau_{c}\right)$ and electron lifetime $\left(\tau_{\mathrm{r}}\right)$, quantifying the results of the previous measurements. ${ }^{8,26}$

Figures $4 \mathrm{a}$ and $4 \mathrm{~b}$ illustrate typical complex plane plots for the IMVS and IMPS responses at $100 \mathrm{~mW}$ of light intensity. In the absence of electron-hole recombination, the phase shift of the IMPS semicircle is the result of the time delay between the generation and collection of charge carriers. ${ }^{27-29}$ At low frequencies, the IMPS plots converge to a point on the real axis that corresponds to the steady-

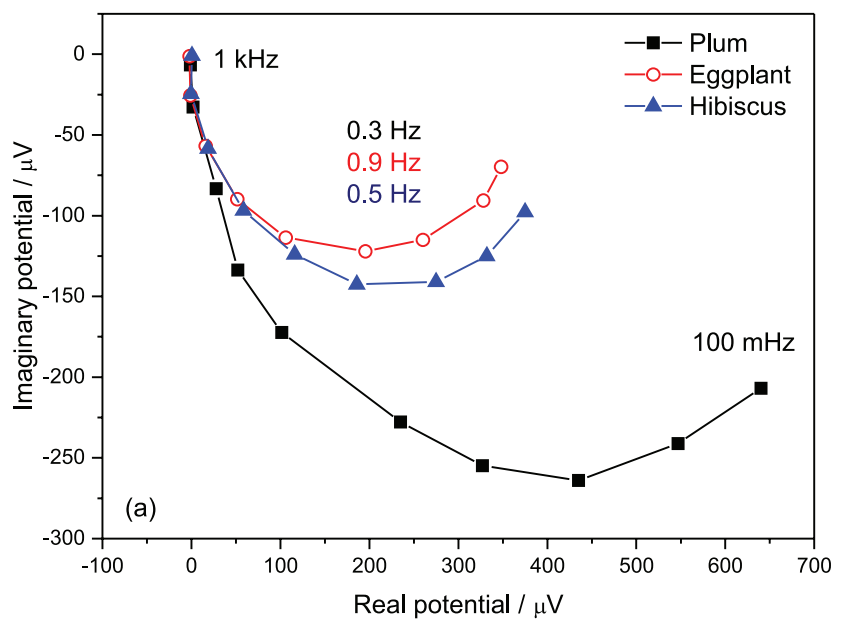

Figure 4. (a) IMVS and (b) IMPS responses to DSSCs with natural dyes. state photocurrent, as described by Ghan et al. ${ }^{27}$ At high frequencies, the modulated photocurrent tends to zero, indicating that the modulation frequency is faster than the relaxation of the charge carrier density, by transport to the contacts and recombination reaction. ${ }^{27,30}$ In the case of the IMVS technique, the response is semicircular, and the phase lag is caused by the relaxation of electrons by back reaction with cations, in the hole conductor matrix, which are assumed to be in excess. ${ }^{30,31}$ The $\tau_{\mathrm{r}}$ can be obtained from the IMVS plot according to the following equation: ${ }^{18}$

$\tau_{\mathrm{r}}(\mathrm{IMVS})=\frac{1}{2 \pi \mathrm{f}_{\mathrm{r}}}$

in which $\mathrm{f}_{\mathrm{r}}$ is the minimum point frequency (in $\mathrm{Hz}$ ) of the IMVS response. The order of magnitude of the mean transit time for photogenerated electrons can be obtained from the frequency minimum in the complex plane IMPS plot, as equation $3::^{18}$

$\tau_{\mathrm{c}}($ IMPS $)=\frac{1}{2 \pi \mathrm{f}_{\mathrm{c}}}$

in which $\mathrm{f}_{\mathrm{c}}$ is the minimum point frequency (in $\mathrm{Hz}$ ) of the IMPS response. The results of $\tau_{\mathrm{c}}$ and $\tau_{\mathrm{r}}$ are shown in Table 1 .

Table 1. Collection time and electron lifetime extract from IMPS and IMVS curves, calculated using equations 2 and 3

\begin{tabular}{lccc}
\hline Dye & $\tau_{\mathrm{c}} / \mathrm{ms}$ & $\tau_{\mathrm{r}} / \mathrm{s}$ & $\eta_{\mathrm{c}}$ \\
\hline Plum peel & 2.35 & 0.51 & 0.99 \\
Eggplant peel & 8.54 & 0.18 & 0.95 \\
Hibiscus flower & 3.80 & 0.30 & 0.98 \\
\hline
\end{tabular}

$\tau_{c}$ : collection time; $\tau_{\mathrm{r}}$ : electron lifetime; $\eta_{\mathrm{c}}:$ charge collection efficiency.

Using the IMPS and IMVS response, it is possible to calculate the charge collection efficiency $\left(\eta_{c}\right)$ for all the systems, employing equation 4 .

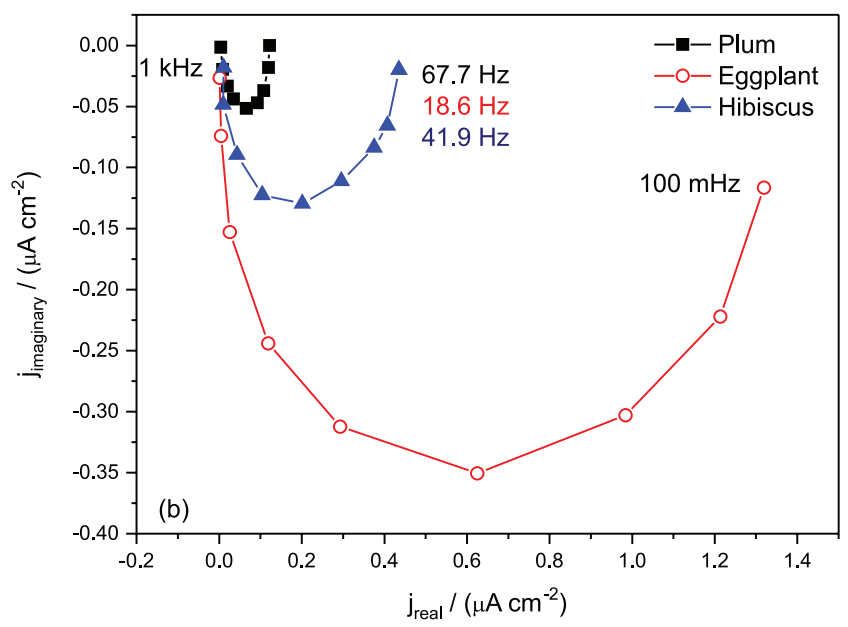


$\eta_{\mathrm{c}}=1-\frac{\tau_{\mathrm{c}}}{\tau_{\mathrm{r}}}$

According to Table 1, the plum dye obtained the highest electron lifetime, $0.51 \mathrm{~s}$, and the best result for collection time, $2.35 \mathrm{~ms}$, when compared with the hibiscus and eggplant dyes, respectively. ${ }^{19}$ All natural dyes have anthocyanidin, a solar active pigment responsible for the harvesting of radiant energy, and this result indicated a large percentage of active substances in its composition. ${ }^{28}$

With better capacity to inject electrons, the cell sensitized with plum is expected to have a higher concentration of electrons in the semiconductor as analyzed by $\mathrm{CE}$ measurement, indicating that these electrons are collected in a shorter time. ${ }^{19}$

For low charge collection efficiency, the variation of $\tau_{\mathrm{c}}$ and $\tau_{\mathrm{r}}$ must be as small as possible. ${ }^{28,29}$ As the time differences of the system are of a high order, all the cells produced showed high-efficiency charge collection of $\eta_{\mathrm{c}}=0.99$ for plum, $\eta_{\mathrm{c}}=0.95$ for eggplant, and $\eta_{\mathrm{c}}=0.98$ for hibiscus. The best result, that for the plum cell, suggests that almost all the incident light is converted to electricity. ${ }^{29-31}$ These results show that, although the cells had different values of IMPS and IMVS, the efficiency of charge collection was close to all the systems.

In Figure 5, the Nyquist plots for all cells produced with natural dyes are shown.

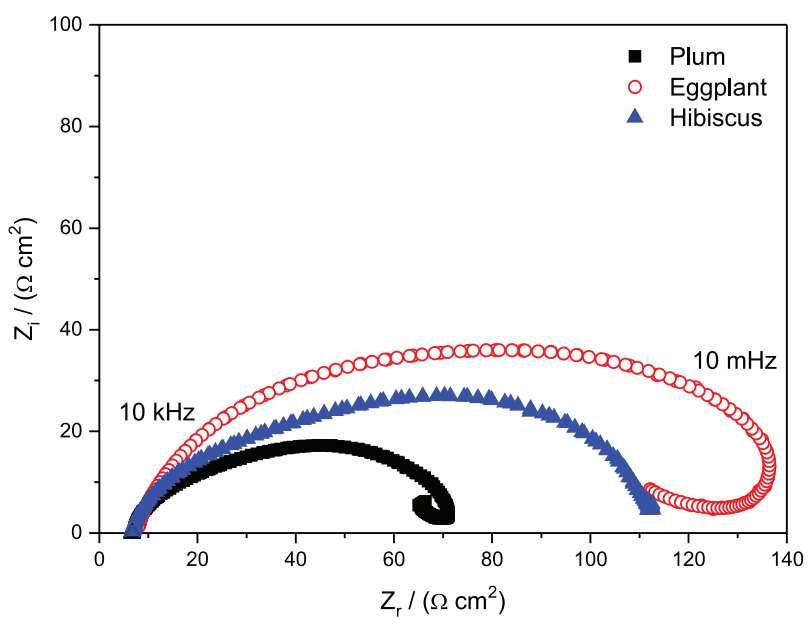

Figure 5. Nyquist plots obtained from EIS measured under AM 1.5G illumination and an open-circuit condition for DSSCs with natural dyes.

Nyquist plots of cells made with ruthenium-based dyes show three semicircles that can be assigned to charge transfer in the counter electrode (high frequency), the electron recombination and electron diffusion in the $\mathrm{TiO}_{2}$ conduction band (CB; intermediary frequency) and the electrolyte diffusion in solution in the low-frequency region. ${ }^{32}$ In the case of the natural dyes tested, only one semicircle was observed, and this behavior can be explained by the charge collection in the photoanode. Because all cells produced low charge collection, there is a small charge transfer to the counter electrode, impeding the semicircle growth at high frequency, as verified in some studies that used natural dyes in DSSCs. ${ }^{23,28}$

Analysis of the cells tested shows that the plum dye can generate devices with less charge transfer resistance because of a lower impedance value, which facilitates the passage of current and consequently improves the photoelectrochemical parameters. ${ }^{33,34}$ The eggplant cell presented a high impedance value because of a larger capacitive arc, which consequently led to lower photoelectrochemical parameters. ${ }^{34}$

To support previous results, the measurements of the $\mathrm{j} v s$. $\mathrm{V}$ curves are shown in Figure 6, and the energy conversion efficiency was calculated using the following equation: ${ }^{35-37}$

$\eta(\%)=\frac{\mathrm{j}_{\mathrm{sc}} \mathrm{V}_{\mathrm{oc}} \mathrm{FF}}{\mathrm{P}_{\text {in }}} \times 100$

The best performance was observed from DSSCs sensitized with plum extract, showing an energy efficiency $(\eta)$ of $0.20 \%$ with an open-circuit potential $\left(V_{o c}\right)$ of $608 \mathrm{mV}$, short-circuit current $\left(\mathrm{j}_{\mathrm{sc}}\right)$ of $0.64 \mathrm{~mA} \mathrm{~cm}^{-2}$, and fill factor (FF) of 0.61 under solar irradiation $\left(\mathrm{P}_{\text {in }}\right)$ of $100 \mathrm{~mW} \mathrm{~cm}^{-2} .^{38-40}$

According to Tsai et al. ${ }^{40} \mathrm{j}_{\mathrm{sc}}$ of a DSSC is influenced by the recombination rate at the interface of natural dye $/ \mathrm{TiO}_{2}$ (reactions 6 and 8, Figure 1) or $\mathrm{TiO}_{2}$ /electrolyte (reaction 7, Figure 1); therefore, the $\mathrm{j}_{\mathrm{sc}}$ performance of a DSSC is improved when the $\tau_{\mathrm{r}}$ decay and $\tau_{\mathrm{c}}$ increase, as observed in the systems analyzed..$^{22,23,41}$

The results obtained confirm that the recombination reaction was more pronounceable for eggplant, and all the photovoltaic parameters for the cells analyzed decreased, generating a device with a solar energy efficiency of $0.15 \%$, which was already expected, because the cell sensitized with eggplant dye presented inferior results of charge transfer resistance, $\mathrm{CE}$, and recombination and collection times when compared with other dyes.

The driving force of the electron transport through the semiconductor network depends on the electron concentration gradient, such as the photosensitization of $\mathrm{TiO}_{2}$ with natural dyes presenting a lower electron concentration in the photoanode caused by lower absorption of sunlight, as shown by the $\mathrm{CE}$ technique. This may restrict the transport of electrons in the semiconductor, in contrast to ruthenium-based dyes (ca. $80 \mu \mathrm{C} \mathrm{cm}^{-2}$ ), leading to a low conversion efficiency. ${ }^{28-30}$

Absorption spectra of dye solution ${ }^{10,42}$ and on $\mathrm{TiO}_{2}$ surface (Figure 7) give useful information about the optical and electrochemical performance of DSSC. ${ }^{39}$ 

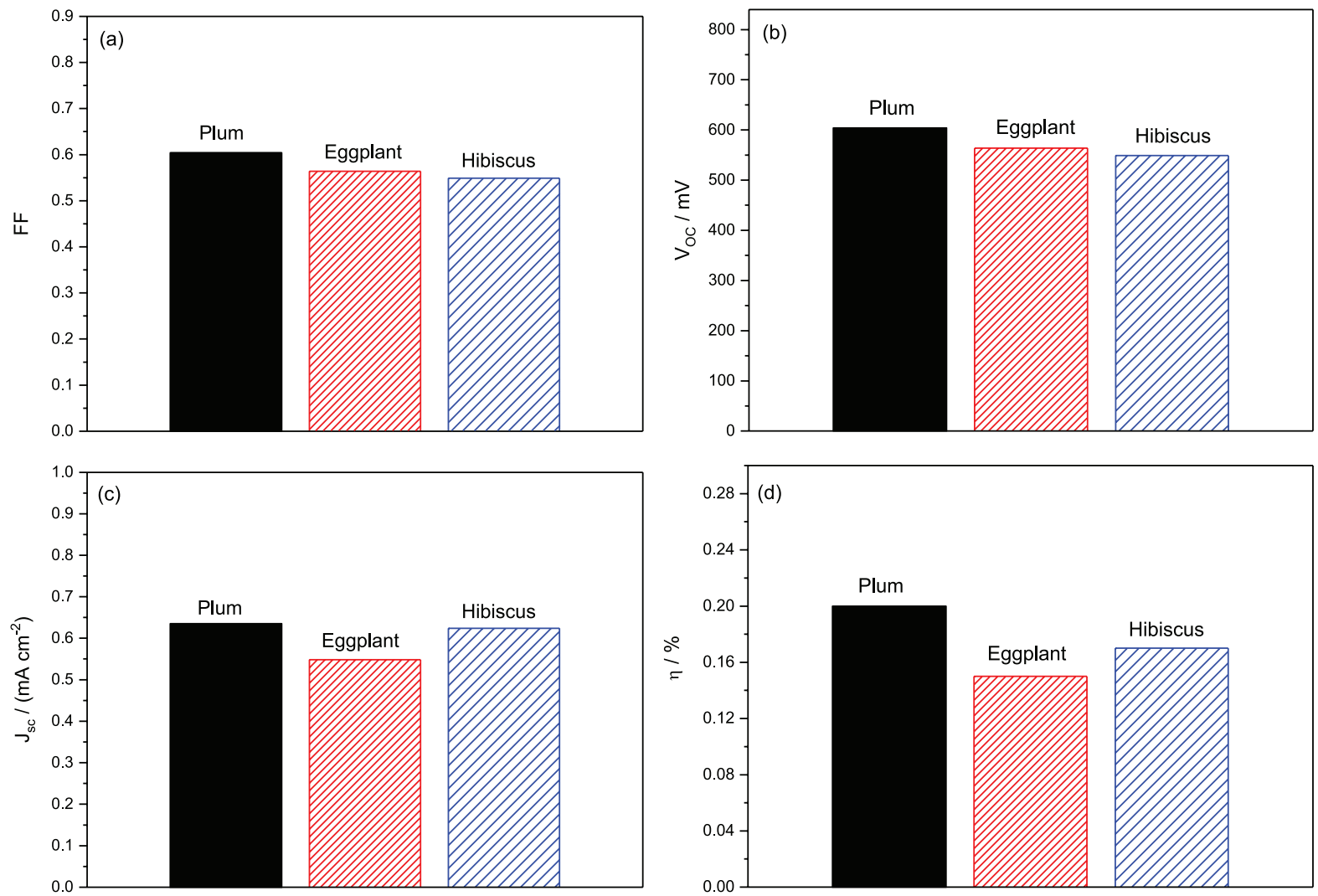

Figure 6. Photovoltaic parameters obtained of the photocurrent density voltage curves for cells with $\mathrm{TiO}_{2}$ and natural dyes, being: (a) fill factor; (b) opencircuit potential; (c) short-circuit current; and (d) global efficiency of sunlight conversion.

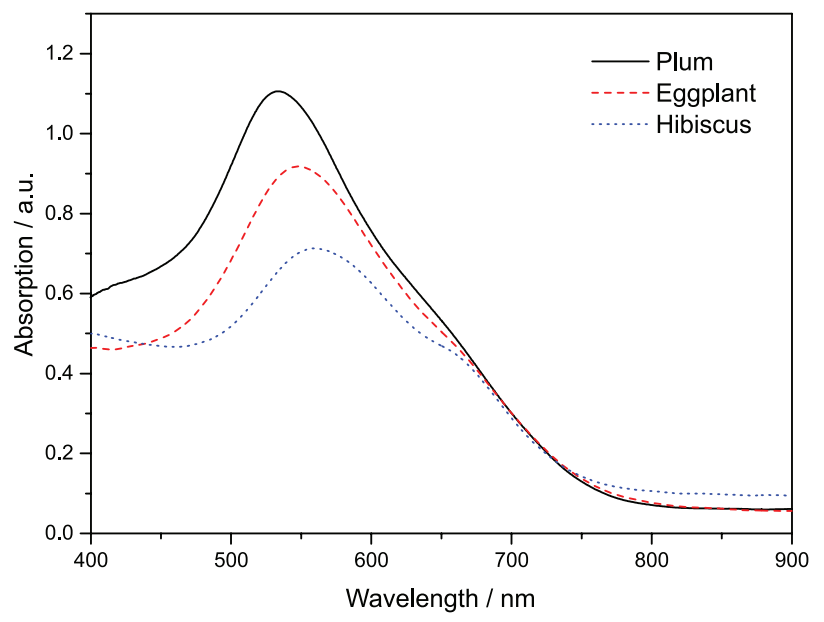

Figure 7. UV-Vis absorption spectra of adsorbed plum, eggplant and hibiscus pigment on $\mathrm{TiO}_{2}$ films.

During $\mathrm{TiO}_{2}$ sensitizing it is expected that the hydroxyl groups of the dye bond to the semiconductor by the condensation of alcoholic bound protons, present in dye solution..$^{29}$ In Figure 7, it is noted that all films have a broad and strong absorption in the visible region $(510-600 \mathrm{~nm})$, confirming the presence of anthocyanidins molecules. ${ }^{39}$ The plum cell showed better results of pigments concentration, due to the high intense absorbance band, resulting in a better adsorption capability of the dye on $\mathrm{TiO}_{2}$ surface, matching the report of the $\mathrm{j} v s$. $\mathrm{V}$ curves. ${ }^{32,42,43}$ It was obtained that all systems are not capable to absorb in infrared region (> $700 \mathrm{~nm}$ ), which partially limits the device harvesting light, as shown by the CE method (Figure 3b). ${ }^{24}$

The electrochemical behavior of the natural dyes was investigated using cyclic voltammetry to evaluate the possibility of charge transfer from dyes to the $\mathrm{TiO}_{2}$ photoelectrode and the results are shown in Figure 8. ${ }^{44}$

The oxidation peak potential for the dyes extracted from

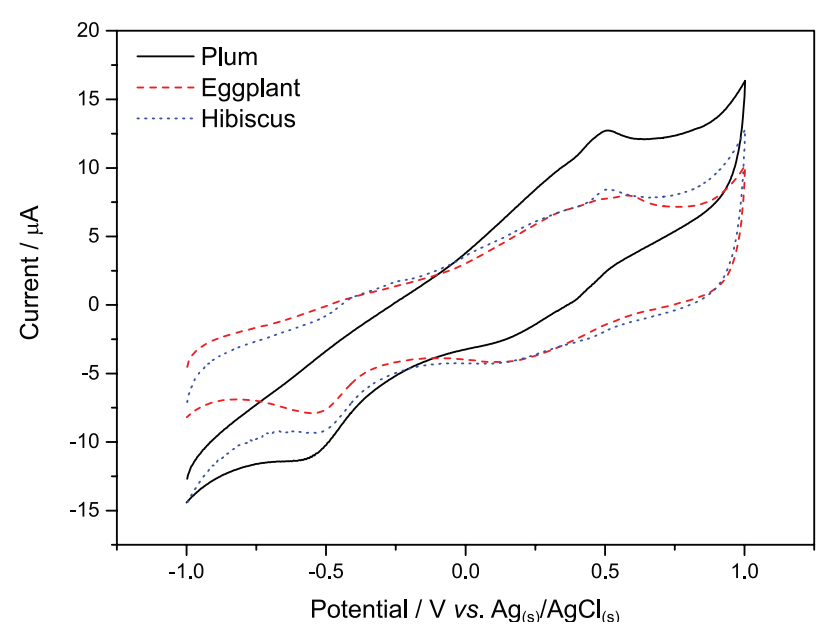

Figure 8. Cyclic voltammograms of anthocyanidins from plum, eggplant and hibiscus extracted in acidified ethanoic solution. 
plum, eggplant, and hibiscus was determined, with values of $+0.49,+0.51$, and $+0.50 \mathrm{~V}$, respectively. The potential of the highest occupied molecular orbital (HOMO) state $\left(\mathrm{E}_{\mathrm{Hомо}}\right)$ was calculated using a correction factor of $4.43 \mathrm{~V}$ for the reference electrode $\mathrm{Ag}_{(\mathrm{s})} / \mathrm{AgCl}_{(\mathrm{s})}$ (equation 6). ${ }^{44}$ Values of $-4.89,-4.91$, and $-4.90 \mathrm{eV}$ were found for plum, eggplant and hibiscus, respectively. The $\mathrm{E}_{\mathrm{GAP}}$ values were estimated using the UV-Vis spectra of Figure 7, as described in papers by Hosseinnezhad et al. ${ }^{45}$ and Crespilho et al. ${ }^{44}$ The potential values for the LUMO state $\left(\mathrm{E}_{\mathrm{LUmo}}\right)$ were calculated by subtraction of $\mathrm{E}_{\mathrm{HOMO}}$ with $\mathrm{E}_{\mathrm{GAP}}$ as discussed by Barea et al. ${ }^{46} \mathrm{The}^{\mathrm{TiO}}$, band gap energy was calculated by Kubelka-Munk method and described in another paper from the present authors. ${ }^{47}$

$\mathrm{E}_{\text {номо }}=-\left(\mathrm{E}_{\text {oxidation }}\right)+(-4.4 \mathrm{~V})$

In Figure 9 is depicted the comparative view of the energy level to the dyes analyzed.

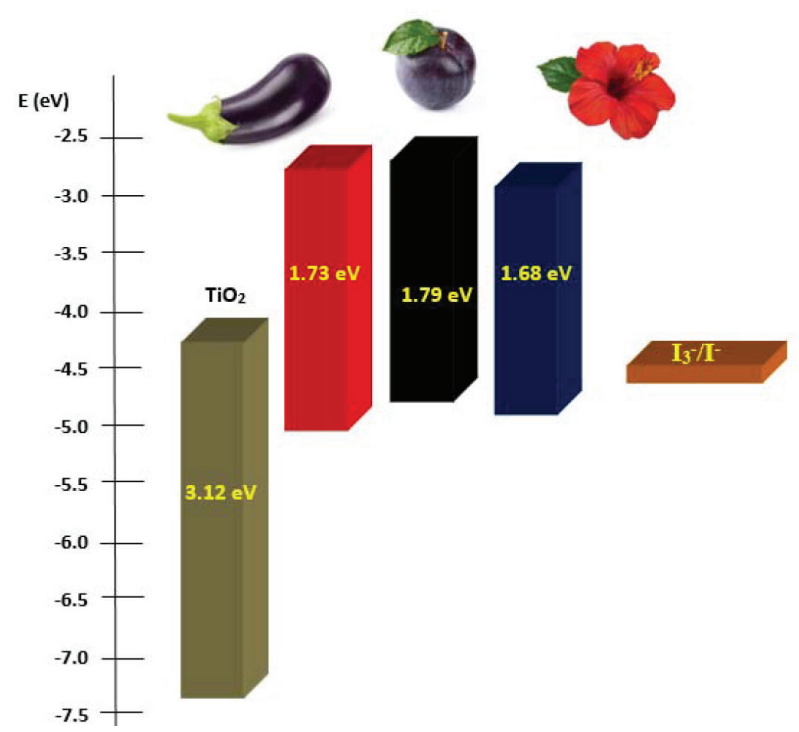

Figure 9. Schematic diagram showing the estimated position of HOMO and LUMO levels and $\mathrm{E}_{\text {gap }}$ of the dyes extracted from eggplant, plum, and hibiscus. Edges of the conduction and valence bands of $\mathrm{TiO}_{2}$ are also shown.

The electrons from the LUMO state could be ejected into the $\mathrm{CB}$ of the semiconductor if the LUMO level of the natural dye is sufficiently more positive when compared with the $\mathrm{CB}$ of $\mathrm{TiO}_{2} \cdot{ }^{5,24}$ Figure 9 shows that all the analyzed dyes are shifted from the $\mathrm{CB}$ of $\mathrm{TiO}_{2}$, favoring the injection of electrons, providing high values of collection efficiency, as calculated using frequency domain techniques. ${ }^{48}$

The dyes showed $\mathrm{E}_{\mathrm{GAP}}$ values of $1.73 \mathrm{eV}$ for eggplant, $1.79 \mathrm{eV}$ for plum, and $1.68 \mathrm{eV}$ for hibiscus, and these values are also close to those in the literature when acidified ethanolic solution was used to extract anthocyanidins. ${ }^{45,48}$
For the dye extracted from the plum, the recombination losses are reduced because the HOMO orbital is positively shifted, resulting in a cell with better electrochemical performance compared with the other dyes studied by Kumara et al..$^{48}$ and Gratzel et al..$^{49}$ This result is equivalent to that obtained using the IMVS technique because the device produced with the plum dye presented a longer recombination time $\left(\tau_{\mathrm{r}}=0.51 \mathrm{~s}\right)$.

For eggplant dye, $\mathrm{E}_{\text {номо }}$ is more negatively displaced, thus providing higher stability characteristics, which consequently favors the recombination of the electrons, as also shown by the time obtained via IMVS for the eggplant cell, $\tau_{\mathrm{r}}=0.18 \mathrm{~s} .^{50,51}$

\section{Conclusions}

The results show that the $\mathrm{TiO}_{2}$ cell sensitized with eggplant peel has more pronounced recombination reactions when compared with plum and hibiscus cells, as demonstrated by the frequency domain techniques.

All the systems analyzed present a great electron lifetime and collection time, however, the CE method indicates a low charge collection on photoanode, due to the anthocyanidin molecule absorb light until the visible range.

Dyes on $\mathrm{TiO}_{2}$ surface absorbed in a visible range, as demonstrated by UV spectra, with better adsorption of anthocyanidin in the plum cell.

Nyquist plots obtained by EIS measurements show the formation of one semicircle, characteristic of the charge transfer to the counter electrode. These results indicate a higher resistance in charge transfer to the cell sensitized with eggplant and a small resistance to the cell sensitized with plum.

The electrochemical results showed that the plum extract is capable of generating a $\mathrm{TiO}_{2}$ cell with less recombination with higher solar energy efficiency of $0.20 \%$, with a $\mathrm{V}_{\mathrm{oc}}=608 \mathrm{mV}, \mathrm{FF}=0.61, \mathrm{j}_{\mathrm{sc}}=0.64 \mathrm{~mA} \mathrm{~cm}^{-2}$, $\tau_{\mathrm{r}}=0.51 \mathrm{~s}, \tau_{\mathrm{c}}=2.35 \mathrm{~ms}, \eta_{\mathrm{c}}=0.99$, and $\mathrm{E}_{\mathrm{gap}}=1.79 \mathrm{eV}$.

\section{Acknowledgments}

The authors are grateful to CNPq, CAPES, SETI/UGF and FINEP for supporting this study, and to Tatiane Valerio and Ketlyn Borth for UV-Vis analyses.

\section{References}

1. Blaszczyk, A.; Dyes Pigm. 2018, 149, 707.

2. Vitoreti, A. B. F.; Vaz, R.; Pena, A. L.; Raphael, E.; Ferrari, J. L.; Shiavon, M. A.; Rev. Virtual Quim. 2017, 9, 4.

3. O’Regan, B.; Gratzel, M.; Nature 1991, 353, 737. 
4. Gratzel, M.; Nature 2001, 414, 338.

5. Kumara, N. T. R. N.; Lim, A.; Lim, C. M.; Petra, M. I.; Ekanayake, P.; Renewable Sustainable Energy Rev. 2017, 78, 301.

6. Thavasi, V.; Renugopalakrishnan, V.; Jose, R.; Ramakrishna, S.; Mater. Sci. Eng., R 2009, 63, 81.

7. Longo, C.; Paoli, M. A.; J. Braz. Chem. Soc. 2003, 14, 889.

8. Li, L. L.; Chang, Y. C.; Wu, H. P.; Diau, E. W. G.; Int. Rev. Phys. Chem. 2012, 31, 420 .

9. Duffy, N. W.; Peter, L. M.; Rajapakse, R. M. G.; Wijayantha, K. G. U.; J. Phys. Chem. B 2000, 104, 8916.

10. Tractz, G. T.; Maia, G. A. R.; Dias, B. V.; Ignachewski, F.; Rodrigues, P. R. P.; Quim. Nova 2018, 41, 512.

11. Xiong, K.; Hou, L.; Wu, M.; Huo, Y.; Mo, W.; Yuan, Y.; Sun, S.; Xu, W.; Wang, E.; Sol. Energy Mater. Sol. Cells 2015, 132, 252.

12. Tractz, G. T.; Maia, G. A. R.; Dias, B. V.; Banczek, E.; Molinares, M. A.; Cunha, M. T.; Rodrigues, P. R. P.; Orbital: Electron. J. Chem. 2018, 10, 204.

13. Wongcharee, K.; Meeyoo, V.; Chavadej, S.; Sol. Energy Mater. Sol. Cells 2007, 91, 566.

14. Kumara, N. T. R. N.; Ekanayake, P.; Lim, A.; Iskandar, M.; Ming, L. C.; Sol. Energy Mater. Sol. Cells 2013, 135, 3.

15. Manhita, A.; Ferreira, T.; Candelas, A.; Dias, C. B.; Anal. Bioanal. Chem. 2011, 400, 1501.

16. Viomar, A.; Maia, G. A. R.; Scremin, F. R.; Khalil, N. M.; Cunha, M. T.; Antunes, A. C.; Rodrigues, P. R. P.; Rev. Virtual Quim. 2016, 8, 889.

17. Narayan, M. R.; Renewable Sustainable Energy Rev. 2012, 16, 208.

18. Lim, A.; Ekanayake, P.; Lim, L. B.; Bandara, J. M. R. S.; Spectrochim. Acta, Part A 2016, 167, 26.

19. Zhang, J.; Peng, W.; Chen, Z.; Chen, H.; Han, L.; J. Phys. Chem. C 2012, 116, 19182.

20. Bailes, M.; Cameron, J.; Lobato, K.; Peter, L. M.; J. Phys. Chem. B 2005, 109, 15429.

21. Boschloo, G.; Hagfeldt, A.; J. Phys. Chem. B 2005, 109, 12093.

22. Kruger, J.; Plass, R.; Gratzel, M.; Cameron, P. J.; Peter, L. M.; J. Phys. Chem. B 2003, 107, 7536.

23. Tsekouras, G.; Myhashita, M.; Kho, Y. K.; Teoh, W. Y.; Mozer, A. J.; IEEE J. Sel. Top. Quantum Electron. 2010, 16, 6.

24. Hagfeldt, A.; Boschloo, G.; Sun, L.; Khloo, L.; Pettersson, H.; Chem. Rev. 2010, 110, 6595.

25. Peter, L. M.; Duffy, N. W.; Wang, R. L.; Wijayantha, K. G. U.; J. Electroanal. Chem. 2002, 524, 127.

26. Zheng, J. W.; Mo, L. E.; Chen, W. C.; Jiang, L.; Ding, Y. C.; Li, Z. Q.; Hu, L. H.; Dai, S. Y.; Electrochim. Acta 2017, 232, 38.

27. Ghan, W.; Kang, H.; Sheikh, T.; Yadav, S.; Gil, T. C.; Nesbitt, F.; Uddin, J.; Sci. Rep. 2016, 7, 41470.

28. Nissfolk, J.; Fredin, K.; Hagfeldt, A.; Boschloo, G.; J. Phys. Chem. Lett. 2006, 110, 17715.

29. Schlinchthorl, G.; Park, N. G.; Frank, A. J.; J. Phys. Chem. B 1999, 103, 782 .
30. Reynal, A.; Forneli, A.; Palomares, E.; Energy Environ. Sci. 2010, 3, 805 .

31. Guimaraes, R. R.; Parussulo, A. L. A.; Marias, T. A.; Toma, H. E.; Araki, K.; Electrochim. Acta 2017, 255, 92.

32. Richhariya, G.; Kumar, A.; Opt. Mater. 2018, 79, 296.

33. Çakar, S.; Ozacar, M.; Spectrochim. Acta, Part A 2016, 163, 79.

34. Al-Alwani, M. A. M.; Mohamad, A. B.; Ludin, N. A.; Kadhum, A. A. H.; Sopian, K.; Renewable Sustainable Energy Rev. 2016, $65,183$.

35. Sonai, G. G.; Melo, M. A.; Nunes, J. H. B.; Megiatto, J. D.; Nogueira, A. F.; Quim. Nova 2015, 10, 1357.

36. Ocakoglu, K.; Yakuphanoglu, F.; Durrant, J. R.; Icli, S.; Sol. Energy Mater. Sol. Cells 2008, 92, 1047

37. Santana Andrade Jr., M. A.; Tiihonen, A.; Miettunen, K.; Lund, P.; Nogueira, A. F.; Pastore, H. O.; ACS Appl. Mater. Interfaces 2017, 9, 20454.

38. Mahalingam, S.; Andullah, H.; Renewable Sustainable Energy Rev. 2016, 63, 245.

39. Shalini, S.; Balasundaraprabhu, R.; Kumar, T. S.; Sivakumaran, K.; Kannan, M. D.; Opt. Mater. 2018, 79, 210.

40. Tsai, J. K.; Hsu, W. D.; Wu, T. C.; Meen, T. H.; Chong, W. J.; Nanoscale Res. Lett. 2013, 8, 459.

41. Calogero, G.; Di Marco, G.; Sol. Energy Mater. Sol. Cells 2008, $92,1341$.

42. Tractz, G. T.; Maia, G. A. R.; Dias, B. V.; Banczek, E. P.; Cunha, M. T.; Rodrigues, P. R. P.; Rev. Virtual Quim. 2018, 10, 1074.

43. Heo, N.; Jun, Y.; Park, J. H.; Sci. Rep. 2013, 3, 1712.

44. Crespilho, F. N.; Zucolotto, V.; Siqueira Jr., J. R.; Carvalho, A. J. F.; Nart, F. C.; Oliveira Jr., O. N.; Int. J. Electrochem. Sci. 2006, 1,151 .

45. Hosseinnezhad, M.; Gharanjig, K.; Moradian, S.; Saeb, M. R.; Energy 2017, 134, 864.

46. Barea, E. M.; Zafer, C.; Gultekin, B.; Aydin, B.; Koyuncu, S.; Icli, S.; Santiago, F. F.; Bisquert, J.; J. Phys. Chem. C 2010, 114, 19840.

47. Dias, B. V.; Tractz, G. T.; Viomar, A.; Maia, G. A. R.; da Cunha, M. T.; Rodrigues, P. R. P.; J. Electron. Mater. 2018, 47, 9.

48. Kumara, N. T. R. N.; Ekanayake, P.; Lim, A.; Iskandar, M.; Ming, L. C.; J. Sol. Energy Eng. 2013, 135, DOI: 10.1115/1.4023877.

49. Gratzel, M.; Durrant, J. R.; Nanostructure and Photoelectrochemical Systems for Solar Photon Conversion, $1^{\text {st }}$ ed.; Imperial College Press: London, 2008.

50. Latif, M. S. A.; Batniji, A.; Agez, T. M.; Younis, M. J.; Ghamri, H.; Thaher, B, A. A.; Qeshta, B. S.; Awwad, F. M. A.; Taya, S. A.; J. Nano- Electron. Phys. 2016, 8, 4.

51. Wu, T. Y.; Tsao, M. H.; Chen, F. L.; Su, S. G.; Chang, C. W.; Wang, H. P.; Lin, Y. C.; Yang, W. C. O.; Sun, I. W.; Int. J. Mol. Sci. 2010, 11, 329.

Submitted: July 17, 2018

Published online: September 21, 2018 